Економічні науки: збірник наукових праць Луиького національного технічного університету. Серія "Регіональна економіка". Випуск 17 (67). Редкол.: відп. ред. к.е.н., професор І.В. Кривов’язюк. Луцьк: ІВВ Луцького НТУ, 2020. 348 с.

УДК 322.122

Подзізей О.О.

Волинський національний університет імені Лесі Українки

\title{
ОСОБЛИВОСТІ РЕАЛІЗАЦІЇ СТРАТЕГІЇ ПІДВИЩЕННЯ КОНКУРЕНТОСПРОМОЖНОСТІ ОБ'ЄДНАНИХ ТЕРИТОРІАЛЬНИХ ГРОМАД В УКРАЇНІ
}

В статті розглянуто специфіку формування конкурентоспроможності об'єднаних територіальних громад в умовах реформування адміністративної системи та бюджетної децентралізації. Визначено необхідність планування послідовності реалізації етапів підвищення конкурентоспроможності об'єднаних територіальних громад (ОТГ) і формування на їх основі стратегії розвитку територіальної громади. Запропоновано алгоритм реалізації стратегії підвищення конкурентоспроможності ОТГ в Україні.
Ключові
слова:
об'єднані
територіальні
громади, конкурентоспроможність, децентралізація, стратегія розвитку.

Podzizei O.O.

\section{PECULIARITIES OF IMPLEMENTATION OF THE STRATEGY OF INCREASING THE COMPETITIVENESS OF UNITED TERRITORIAL COMMUNITIES IN UKRAINE}

The implementation of tasks to ensure the growth of UTC competitiveness is possible only through the formation of an effective and efficient model to increase its competitiveness. However, the implementation of such a task involves the implementation of successive steps to plan this model and the implementation of the tasks set in it, in accordance with the overall strategic plan for the development of the territorial community. Therefore, in the process of implementing the strategy of increasing the competitiveness of UTC it is necessary to form a scheme of its sequence, which, in our opinion, should include the following successive stages:

Analysis of the current situation and identification of community development needs. This stage should precede the formation of plans to increase competitiveness, and its main task is to answer the question - what exactly needs to be achieved, what resources and how much is available to the local community and whether they are enough to implement the plans.

The second important aspect of the analytical activity should be the study of the needs of the local population and business structures, the study of their vision of the development of the territorial community. It is no secret that the main goal of decentralization reform is to transfer decision-making powers to local governments, which know best the needs of the population. Therefore, the widest possible 
Економічні науки: збірник наукових праць Луиького національного технічного університету. Серія "Регіональна економіка". Випуск 17 (67). Редкол.: відп. ред. к.е.н., професор І.В. Кривов’язюк. Луцьк: ІВВ Луцького НТУ, 2020. 348 с.

consideration of public opinion will allow to form such development plans of the territory, which will receive comprehensive support from local residents and local businesses, which will automatically increase the effectiveness of plans and tasks to increase the competitiveness of UTC.

Formation of plans to increase the competitiveness of UTC. At this stage, first of all, it is necessary to determine the mission of the strategic community development plan. This is necessary to maximize the need for and relevance of the tasks to be identified in the plan and to ensure that all stakeholders involved in the implementation of this plan understand this relevance. Accordingly, the next element of planning will be to determine the priority areas of development of the territorial community and on their basis to determine measures to improve its competitiveness. The key point here is to align priorities with available resources that should ensure the implementation of the plan.

In our opinion, the most important stage of increasing the competitiveness of united territorial communities is the implementation of the set tasks and plans. At the same time, this stage for the UTC itself is to establish a system of administrative regulation of the implementation of pre-defined plans, as the direct implementation of development projects is carried out by business entities in the implementation of investment or infrastructure projects. Therefore, at this stage the local community is required to form an effective system for monitoring the implementation of plans and bring the management structure of the local community to a level where it will be able to monitor the implementation of UTC decisions and carry out their prompt correction and refinement accordingly and depending on the strategic development plan. and an overall increase in the competitiveness of UTC.

Key words: UTC, competitiveness, decentralization, development strategy.

\section{Подзизей O.O. \\ ОСОБЕННОСТИ РЕАЛИЗАЦИИ СТРАТЕГИИ ПОВЫШЕНИЯ КОНКУРЕНТОСПОСОБНОСТИ ОБЪЕДИНЕННЫХ ТЕРРИТОРИАЛЬНЫХ ОБЩИН В УКРАИНЕ}

В статье рассмотрена специфика формирования конкурентоспособности объединенных территориальных общин в условиях реформирования административной системы и бюджетной децентрализации. Определена необходимость планирования разработки последовательности реализации этапов повышения конкурентоспособности объединенных территориальных общин (ОТО) и формирование на их основании стратегии развития территориальной общины в целом. Предложено алгоритм реализации стратегии повышения конкурентоспособности ОТО в Украине.

Ключевые слова: объединенные территориальные общины, конкурентоспособность, децентрализация, стратегия развития. 
Економічні науки: збірник наукових праць Луиького національного технічного університету. Серія "Регіональна економіка". Випуск 17 (67). Редкол.: відп. ред. к.е.н., професор І.В. Кривов'язюк. Луиьк: ІВВ Луцького НТУ, 2020. 348 с.

Постановка проблеми у загальному вигляді та їі зв'язок 3 важливими науковими та практичними завданнями. Одним із найважливіших наслідків зростання конкурентоспроможності територіальних громад в Україні $\epsilon$ покращення загального стану та фінансової стійкості громади, що відбувається за рахунок оптимізації інвестиційного клімату та залучення додаткових фінансових ресурсів. При цьому внаслідок підвищення рівня конкурентоспроможності територіальної громади зростає фінансова віддача суб'єктів підприємництва від реалізації залучених інвестиційних проектів. Таким чином, реалізація планів щодо підвищення конкурентоспроможності територіальної громад буде мати наслідком зростання фіскальних надходжень до місцевого бюджету, що покращить можливості об'єднаних територіальних громад (ОТГ) щодо фінансування поточних потреб i розширення перспективних планів розвитку громади.

Аналіз останніх досліджень, у яких започатковано вирішення проблеми. Дослідженням проблем підвищення конкурентоспроможності територіальних громад присвячено чимало праць таких вітчизняних дослідників, як Б. Андрушків [1], О. Гавриш [2], І. Дегтярьова [3], С. Кльоба [4], С. Співак [5], Т. Шматковська $[6 ; 7 ; 8]$ тощо. Проте, особливості поточного етапу дослідження розвитку регіонів та територіальних громад потребують поглибленого вивчення питань забезпечення конкурентоспроможності територіальних громад в Україні.

Цілі статті. Метою роботи $є$ визначення особливостей формування стратегії послідовної реалізації підвищення конкурентоспроможності об'єднаних територіальних громад.

Викладення основного матеріалу дослідження 3 повним обгрунтуванням отриманих наукових результатів. Реалізація завдань по забезпеченню зростання конкурентоспроможності ОТГ $є$ можливою лише через формування дієвої та ефективної моделі підвищення іï конкурентоспроможності. Проте реалізація такого завдання передбачає здійснення послідовних кроків по плануванню цієї моделі та по реалізації поставлених у ній завдань, відповідно до 
Економічні науки: збірник наукових праць Луиького національного технічного університету. Серія "Регіональна економіка". Випуск 17 (67). Редкол.: відп. ред. к.е.н., професор І.В. Кривов'язюк. Луиьк: ІВВ Луцького НТУ, 2020. 348 с.

загального стратегічного плану розвитку територіальної громади. Однак дані дії також не є простими за своєю сутністю і передбачають ряд послідовних кроків від постановки завдань по підвищенню конкурентоспроможності, до прорахунку обсягу ресурсів та часу, необхідних на їх реалізацію, а також визначення послідовності реалізації цих планів.

Тому в процесі реалізації стратегії підвищення конкурентоспроможності ОТГ необхідно сформувати алгоритм забезпечення іiі послідовності, який, на нашу думку, повинен включати в себе наступні послідовні етапи:

1. Аналіз поточної ситуації та визначення потреб розвитку громади. Даний етап повинен передувати формуванню планів підвищення конкурентоспроможності, а його головним завданням є дати відповідь на питання - що саме потрібно досягти, які саме ресурси та в якій кількості $є$ у наявності територіальної громади і чи вистачить їх для реалізації планів.

Другим аспектом аналітичної діяльності повинне стати дослідження потреб місцевого населення та підприємницьких структур, вивчення їх бачення розвитку територіальної громади, адже головною метою реформи децентралізації $\epsilon$ передача повноважень прийняття рішень органам місцевого самоврядування, які найкраще знають потреби населення.

Завершальним етапом аналізу ситуації повинне стати визначення сильних та слабких сторін територіальної громади у поточній ситуації, яке варто здійснювати шляхом проведення SWOT-аналізу ситуації. Таким чином, буде одержано найбільш інформативні дані для переходу до наступного етапу стратегічного планування.

2. Формування планів

підвищення конкурентоспроможності ОТГ. На даному етапі необхідно визначити місію стратегічного плану розвитку громади для максимального розкриття необхідності та актуальності завдань, що будуть визначені в плані та для забезпечення розуміння цієї актуальності усіма суб'єктами, котрі будуть приймати участь в реалізації цього плану. Тому наступним елементом планування $\epsilon$ визначення пріоритетних напрямів розвитку територіальної 
Економічні науки: збірник наукових праць Луиького національного технічного університету. Серія "Регіональна економіка". Випуск 17 (67). Редкол.: відп. ред. к.е.н., професор І.В. Кривов'язюк. Луиьк: ІВВ Луцького НТУ, 2020. 348 с.

громади і на їх основі визначення заходів по підвищенню іï конкурентоспроможності та необхідність узгодження пріоритетів з наявними ресурсами для реалізації плану.

Також необхідно зазначити про потребу в окремому визначенні стратегічних та оперативних цілей розвитку територіальної громади та відображення їх, відповідно, у стратегічному плані та поточних планах реалізації поставлених завдань. При цьому самі завдання розвитку ОТГ повинні також бути узгоджені 3 даними планами 3 врахуванням 3 вимогами адміністративної та бюджетної децентралізації.

3. Найбільш важливим етапом підвищення конкурентоспроможності об'єднаних територіальних громад $є$, на нашу думку, реалізація поставлених завдань та планів. При цьому, даний етап 3 для самої ОТГ полягає в налагодженні системи адміністративного регулювання порядку реалізації поперед визначених планів, оскільки безпосередня реалізація проектів розвитку здійснюється суб'єктами підприємницької діяльності в процесі реалізації інвестиційних або інфраструктурних проектів. Тому на даному етапі від територіальної громади вимагається сформувати ефективну систему моніторингу реалізації планів та довести структуру управління територіальною громадою до такого рівня, коли вона буде здатна як контролювати виконання рішень ОТГ, так i здійснювати оперативну їх корекцію та уточнення відповідно та в залежності від стратегічного плану розвитку та загального підвищення конкурентоспроможності ОТГ.

Висновки. Таким чином можна визначити, що конкурентоспроможність територіальних громад являє собою їх потенційні можливості ефективно функціонувати в умовах конкурентного середовища 3 врахуванням ресурсного забезпечення та поточного рівня економічного розвитку, що матиме наслідком зростання рівня продуктивності підприємств регіону та підвищення рівня i якості життя населення територіальної громади. При цьому послідовність реалізації стратегії підвищення конкурентоспроможності ОТГ повинна включати в себе три ключових етапи, логічним наслідком вдалої 
Економічні науки: збірник наукових праць Луиького національного технічного університету. Серія "Регіональна економіка". Випуск 17 (67). Редкол.: відп. ред. к.е.н., професор І.В. Кривов'язюк. Луиьк: ІВВ Луцького НТУ, 2020. 348 с.

реалізації яких стане формування стратегії підвищення конкурентоспроможності ОТГ в реаліях їх функціонування, завдяки чому і буде досягнуто мету стратегічного планування розвитку територіальної громади.

\section{Список бібліографічного опису}

1. Андрушків Б.М., Кирич Н.Б., Латинін М.А., Погайдак О.Б., Співак С.М. Особливості формування добровільних конкурентоспроможних об'єднань територіальних громад в умовах децентралізації: проблеми та перспективи моделювання процесу. Теорія та практика державного управління. 2017. №2 (57). С. 1-8.

2.Гавриш О.А., Войтко С.В. Компаративний аналіз загроз економічному виміру для адміністративно-територіальних одиниць 3 використанням методології сталого розвитку (докризовий і кризовий періоди). Економічний вісник НТУУ “КПІ”. 2012. №9. С. 10-15.

3.Дегтярьова I.O. Фактори підвищення конкурентоспроможності сучасного регіону. Державне управління: теорія та практика. 2009. №1(9).

4.Кльоба С.М. Соціально-економічна сутність критеріїв конкурентоспроможності об'єднаних територіальних громад. Регіональна економіка. 2018. №3. С. 36-43.

5.Співак С.М. Підвищення конкурентоспроможності підприємств як основа фінансової спроможності об'єднаної територіальної громади. Причорноморські економічні студії. 2018. Вип. 32. С. 70-77.

6.Шматковська Т.О., Поліщук В.Л. До питання трактування економічної сутності оборотного капіталу в аспекті особливостей функціонування торговельних підприємств. Економічний вісник Донбасу. 2012. №3 (29). C. 119-122.

7.Шматковська Т.О., Мачулка О.В. Концептуальні засади стратегічного управлінського обліку. Науковий вісник Одеського наиіонального економічного університету. - Науки : економіка. 2016. № 4 (236). С. 242-253. ULR: http://nvisnik.oneu.edu.ua/files/archive/nv_4_(236)_2016.pdf

8.Шматковська Т., Демедюк Л., Рудь Т. До проблематики генезису та дефініції економічної категорії «витрати». Науковий вісник ГОдеського начіонального економічного університету]. 2016. № 2. С. 169-182. URL: http://nbuv.gov.ua/UJRN/Nv 2016216

\section{References}

1.Andrushkiv B.M., Kyrych N.B., Latynin M.A., Pogajdyk O.B., Spivak S.M. Osoblyvosti formuvannia dobrovilnyh konkurentospromozhnyh ob'ednan terytorialnyh gromad $\mathrm{v}$ umovah dezentralizazii: problem ta perspektyvy modeliuvannia procesu [Peculiarities of formation of voluntary competitive associations of territorial communities in the conditions of decentralization: problems and prospects of process modeling]. Theory and practice of public administration. 2017. Vol 2 (57). Pp. 1-8 [in Ukrainian]. 
Економічні науки: збірник наукових праць Луиького національного технічного університету. Серія "Регіональна економіка". Випуск 17 (67). Редкол.: відп. ред. к.е.н., професор І.В. Кривов’язюк. Луцьк: ІВВ Луцького НТУ, 2020. 348 с.

2.Gavrysh O.A., Voitko S.V. Komparatyvnyj analiz zagroz ekonomichnomu vymiru dlia administratyvno-terytorialnyh odynyc z vykorystanniam metodologiyi stalogo rozvytku (dokryzovyi i kryzovyi periody) [Comparative analysis of the threat of economic dimension for administrative-territorial units using the methodology of sustainable development (pre-crisis and crisis periods)]. Economic Bulletin of NTUU «KPI». 2012. Vol. 9. Pp. 10-15 [in Ukrainian].

3.Degtiariova I.O. Faktory pidvyshchennia konkurentospromozhnosti suchasnogo regionu [Factors to increase the competitiveness of the modern region]. Public administration: theory and practice. 2009. Vol. 1(9). [in Ukrainian].

4.Klioba S.M. Social `no-ekonomichna sutnist` kryteriyiv konkurentospromozhnosti obiednanyh terytorial'nyh gromad [Socio-economic essence of the criteria of competitiveness of united territorial communities]. Regional economy. 2018. Vol. 3. Pp. 36-43 [in Ukrainian].

5.Spivak S.M. Pidvyshhennia konkurentospromozhnosti pidpryiemstv yak osnova finansovoi spromozhnosti obiednanoyi terytorial noi gromady [Increasing the competitiveness of enterprises as a basis for the financial capacity of the united territorial community]. Black Sea Economic Studies. 2018. Vol. 32. Pp. 70-77 [in Ukrainian].

6.Shmatkovska T.O., Polishchuk V.L. Do pytannia traktuvannia ekonomichnoi suynosti oborotnogo kapitalu v aspekti osoblyvostei funkcionuvannia torhivelnyh pidpryiemstv [On the question of interpretation of the economic essence of working capital in terms of the peculiarities of the functioning of commercial enterprises]. Ekonomichnyi visnyk Donbasu - Economic Bulletin of Donbas. 2012. Vol. 3 (29). Pp. 119-122 [in Ukrainian].

7.Shmatkovska T.O., Machulka O.V. Konceptualni zasady strategichnogo upravlinskogo obliku [Conceptual principles of strategic management accounting]. Naukovyi visnyk Odeskogo nacionalnogo ekonomichnogo universytetu. Ekonomika - Scientific Bulletin of Odessa National Economic University. Economy. 2016. Vol. 4 (236). Pp. 242-253. [in Ukrainian].

8.Shmatkovska T., Demedyuk L., Rud T. Do problematyky genezysu ta definiciyi ekonomichnoyi kategoriyi «vytraty»[On the problems of genesis and definition of the economic category «costs»]. Naukovyj visnyk Odeskogo nacionalnogo ekonomichnogo universytetu - Scientific Bulletin of Odesa National Economic University. 2016. Vol. 2. Pp. 169-182 [in Ukrainian]. 